\title{
PENGARUH PEMBERIAN DOSIS PUPUK N DAN P \\ TERHADAP PERTUMBUHAN DAN HASIL KACANG PANJANG (Vigna Sinensis L)
}

\author{
Murdaningsih ${ }^{1}$, Yohanes Karol Mbia Wae ${ }^{2}$ \\ Ningsih_murda@yahoo.co.id
}

\section{Program Studi Agroteknologi, Fakultas Pertanian-Universitas Flores}

\begin{abstract}
The purpose of this research is to know whether the influence of using fertilizer $\mathrm{N}$ and $\mathrm{P}$ dosage towards the growth and yield of long beans (vigna sinesis L). This research was carried out in Onelako Village, Ndona subdistrict of Ende regency.

The method used was Randomized Block Design with two factor of treatments and three replications. The first factor is nitrogen fertilizer which consists of three dosages namely N0: (non-nitrogen fertilizer), N1 (30 kg/ha), N2 (60 kg/ha) and second factor is phosphor fertilizer which comprises three dosage: P0 (non-phosphor fertilizer)), P1 (50 $\mathrm{kg} / \mathrm{ha}$ ) and P2 (100 kg/ha). Observation variables are the dimater of rod, leaf number, leaf area, pods length, pods diameter, pods number, fresh weight of pods/plants, fresh weight of pods/ha, freshmaximal yield and residues/ha and harvest index.

The result showed that no interaction between two factors of treatment $(\mathrm{N} \times \mathrm{P})$. Nitrogen fertilization treatment of 60 and phosphor with dosage of $100 \mathrm{~kg} / \mathrm{ha}(\mathrm{P} 2)$ produce the best yields towards all observation variables. The yields of fresh weight of pods per highest plant is 62,56 gr acquired from plants which get N2 and P2 fertilizer. However, the treatments between $\mathrm{N} 1$ and $\mathrm{N} 2$ do not have real different in all observation variables as well as treatment of P1 and P2.
\end{abstract}

Keywords: Nitrogen, phosphor, growth and yield of long beans

\section{PENDAHULUAN}

Tanaman kacang panjang (Vigna sinensis L.) adalah sayuran multiguna karena selain berguna sebagai bahan pangan, kacang panjang juga mengandung unsur-unsur yang bermanfaat bagi kesehatan manusia. Selain itu kacang panjang juga mengandung antioksidan yang berperan mencegah kanker (Suryadi, 2003 ).
Menurut data BPS Kabupaten Ende ( 2012 ), luas area tanaman kacang panjang nasional pada tahun 2010 seluas 83.769 ha dan produksi sebesar 483.793 ton sedangkan pada tahun 2011 luas areanya seluas 85.828 ha dan produksi sebesar 489.449 ton dengan tingkat produktivitas pada tahun 2010 sebesar 5,77 ton/ha dan pada tahun 2011 sebesar 5,70 ton/ ha. Untuk wilayah provinsi NTT luas area 
Murdaningsih: Pengaruh pemberian dosis pupuk $\mathrm{N}$ dan $\mathrm{P}$ Terhadap pertumbuhan dan hasil Kacang panjang (Vigna sinensis $\mathrm{L}$ )

tanaman kacang panjang pada tahun 2010 seluas 1194 ha dan produksi sebesar 4178 ton sedangkan pada tahun 2011 luas area sebesar 1027 ha dan produksi sebesar 3445 ton dengan tingkat produktivitas pada tahun 2010 sebesar 3,49 ton/ha dan pada tahun 2011 sebesar 3,35 ton/ha. Untuk wilayah Kabupaten Ende luas area tanaman kacang panjang pada tahun 2010 seluas 1.140 ha dan produksi 798 ton sedangkan luas area pada tahun 2011 seluas 1.140 dan produksi 273 ton, dengan tingkat produktivitas pada tahun 2010 sebesar 0,7 ton/ha dan pada tahun 2011 sebesar 0,2 ton/ha.

Dilihat dari tingkat produksi dan produktivitas tanaman kacang panjang mengalami penurunan. Penurunan produksi kacang panjang disebabkan para petani kurang memperhatikan proses pemupukan pada awal pertumbuhan tanaman kacang panjang. Karena kebanyakan para petani dalam proses pembudidayaan tidak menggunakan pupuk atau menggunakan pupuk masih tidak sesuai dengan dosis dan kandungan unsur haranya. Menurut Setiadi (1995), untuk dapat meningkatkan produktivitas kacang panjang harus diikuti dengan peningkatan ketersediaan unsur hara dalam tanah. Salah satunya adalah memperbaiki dan meningkatkan kesuburan tanah melalui pemupukan dengan dosis yang tepat, pemupukan itupun harus sesuai dengan tingkat kebutuhan tanaman akan ketersediaan hara di dalam tanah.

Pada umumnya kemampuan tanah menyediakan hara, dapat mencerminkan tingkat kesuburan tanah dan berkorelasi positif dengan hasil tanaman. Di lain pihak tingkat kesuburan tanah berkorelasi negatif dengan kebutuhan pupuk dapat diartikan makin tinggi tingkat kesuburan tanah, maka makin rendah penggunaan pupuk dan tidak perlu ditambahkan. Tetapi jika jumlah unsur hara tidak dapat memenuhi kebutuhan tanaman maka perlu ditambahkan nutrisi dalam bentuk pupuk.

Hasil tanaman sangat ditentukan oleh ketersediaan unsur hara, penambahan unsur hara dapat dilakukan melalui pemupukan. Menurut Theresia (2007), jumlah pupuk yang diberikan berhubungan dengan kebutuhan tanaman akan unsur hara, kadar unsur hara yang ada dalam tanah, serta kadar unsur hara yang ada dalam pupuk. Pertumbuhan tanaman akan terhambat bila jumlah unsur hara dalam tanah 
Murdaningsih: Pengaruh pemberian dosis pupuk $\mathrm{N}$ dan $\mathrm{P}$ Terhadap pertumbuhan dan hasil Kacang panjang (Vigna sinensis $\mathrm{L}$ )

kurang, tidak tersedia atau unsur lainnya dibutuhkan tetapi dalam ketersediaannya lambat dan jika unsurunsur hara tersebut dalam jumlah tidak cukup seimpbang dengan unsur lain.

Karena selain unsur hara dalam tanah, diperlukan juga unsur hara makro yang diperlukan tanaman kacang panjang untuk mendukung pertumbuhan serta meningkatkan hasil produksi, unsur hara makro yang dibutuhkan oleh tanaman kacang panjang yaitu unsur nitrogen dan fosfor. Pemupukan nitrogen diperlukan terutama pada awal pertumbuhan sampai terjadinya simbiosis secara efektif, karena pada masa awal pertumbuhan tanaman bagian yang pertama tumbuh dan berkembang adalah bagian vegetatif tanaman seperti akar, batang dan daun sehingga apabila kekurangan unsur nitrogen maka proses pertumbuhan menjadi terhambat (Winarso. S, 2003). Selain itu kekurangan unsur nitrogen juga mengakibatkan proses infeksi oleh rhizobia pada akar akan terganggu, sehingga fiksasi $\mathrm{N}$ menjadi rendah. Kebutuhan tanaman kacang panjang akan unsur hara yang sangat besar terhadap unsur nitrogen dan fosfor yaitu nitogen dibutuhkan sebanyak $100 \mathrm{~kg} / \mathrm{ha}$ dan fosfor $200 \mathrm{~kg} / \mathrm{ha}$ sedangkan unsur jumlah kecil.

Menurut hasil penelitian Mapegau (2007) menunjukan bahwa pemberian pupuk nitrogen sebanyak $30 \mathrm{~kg} / \mathrm{ha}$ hingga $60 \mathrm{~kg} / \mathrm{ha}$ berpengaruh nyata dalam meningkatkan tinggi sebesar 46 cm dan luas daun tanaman sebesar 256, $89 \mathrm{~cm} 2$, bobot biji kering (hasil) kacang hijau meningkat pada pemupukan nitrogen sebanyak $30 \mathrm{~kg} / \mathrm{ha}$ hingga 45 $\mathrm{kg} / \mathrm{ha}$ sebesar1,107 ton/ha dan 1,115 ton/ha, sedangkan menurut hasil penelitian I Putu Wisardja (2010) menunjukan bahwa pemberian dosis pupuk Phosfat sebanyak $100 \mathrm{~kg} / \mathrm{ha}$ berpengaruh nyata dalam peningkatan berat polong tanaman kacang panjang sebesar 14,23 ton/ha .

Berdasarkan uraian di atas maka penulis merasa tertarik untuk melakukan penelitian terhadap “6 Pengaruh Pemberian Dosis Pupuk N dan P Terhadap Pertumbuhan dan Hasil Kacang Panjang (Vigna Sinensis L)““.

\section{METODE PENELITIAN}

\section{Tempat dan Waktu}

Penelitian ini dilaksanakan di Kelurahan Onelako, Kecamatan Ndona, Kabupaten Ende dan waktu penelitian dari bulan Februari-Mei 2013. 
Murdaningsih: Pengaruh pemberian dosis pupuk $\mathrm{N}$ dan $\mathrm{P}$ Terhadap pertumbuhan dan hasil Kacang panjang (Vigna sinensis $\mathrm{L}$ )

\section{Bahan dan Alat}

Bahan yang digunakan dalam penelitian ini: benih kacang panjang varietas putih super, pupuk SP 36, pupuk urea, pupuk kandang ayam. Alat yang digunakan adalah cangkul, parang, tugal, gembor, jangka sorong, alat tulis, kamera, kertas milimeter.

\section{Rancangan Penelitian}

Percobaan ini disusun berdasarkan Rancangan Acak Kelompok (RAK) faktorial yang diulang sebanyak 3 kali.

Faktor I : pupuk N dengan 3 taraf perlakuan yaitu

$$
\begin{aligned}
& \mathrm{N} 0=\text { Tanpa Pupuk ( Kontrol) } \\
& \mathrm{N} 1=30 \mathrm{~kg} / \mathrm{ha} \mathrm{N}=1257 \mathrm{~kg} / \mathrm{ha} \text { urea } \\
& (440 \text { gram } / \text { petak ) } \\
& \mathrm{N} 2=60 \mathrm{~kg} / \mathrm{ha} \mathrm{N}=2514 \mathrm{~kg} / \mathrm{ha} \text { urea } \\
& (900 \text { gram/petak ) }
\end{aligned}
$$

Faktor II : pupuk P dengan 3 taraf perlakuan yaitu

$$
\begin{aligned}
& \text { P0 = Tanpa Pupuk ( Kontrol }) \\
& \mathrm{P} 1=50 \mathrm{~kg} / \mathrm{ha} \mathrm{P} 2 \mathrm{O} 5=2742,9 \mathrm{~kg} / \mathrm{ha} \\
& \text { SP } 36 \text { ( } 960 \text { gram/petak ) } \\
& \mathrm{P} 2=100 \mathrm{~kg} / \mathrm{ha} \mathrm{P} 2 \mathrm{O} 5=2514 \mathrm{~kg} / \mathrm{ha} \\
& \text { SP } 36 \text { ( } 1940 \text { gram/petak ) }
\end{aligned}
$$

Sehingga diperoleh 9 kombinasi perlakuan yaitu:

$\begin{array}{lll}\text { N0P0 } & \text { N1P0 } & \text { N2P0 } \\ \text { N0P1 } & \text { N1P1 } & \text { N2P1 } \\ \text { N0P2 } & \text { N1P2 } & \text { N2P2 }\end{array}$

Setiap perlakuan akan diulang sebanyak 3 kali sehingga terdapat 27 bedengan: denah percobaan terlampir.

\section{Perlakuan Penelitian}

Perlakuan dalam penelitian ini adalah:

\section{Persiapan Lahan}

Lahan terlebih dahulu dibersihkan dari rumput-rumput liar, setelah itu tanah dicangkul sedalam $30 \mathrm{~cm}$ agar tanah menjadi remah, gembur dan berdrainase baik. Di sekeliling lahan dibuat parit untuk keperluan pemasukan air dan pengeluaran sisa air pengairan. Selanjutnya dibuat bedengan dengan lebar $140 \mathrm{~cm}$, tinggi sekitar $30 \mathrm{~cm}$, jarak antar bedengan $30 \mathrm{~cm}$ dan panjang bedengan $250 \mathrm{~cm}$.

\section{Penanaman}

Waktu tanam pada awal musim kemarau. Pembuatan lubang tanam dapat dilakukan dengan menggunakan tugal, jarak antar lubang tanam 30 X 50 $\mathrm{cm}$. Cara penanaman, benih dimasukan ke dalam lubang tanam sebanyak 3 biji kemudian lubang tersebut ditutup dengan tanah.

\section{Pemupukan}

Pada saat pembentukan bedengan diberikan pupuk kandang dengan dosis 15,7 ton/ha dengan dosis per petak sebanyak 5500 gr/petak. 
Murdaningsih: Pengaruh pemberian dosis pupuk $\mathrm{N}$ dan $\mathrm{P}$ Terhadap pertumbuhan dan hasil Kacang panjang (Vigna sinensis $\mathrm{L}$ )

Pupuk tersebut digunakan sebagai pupuk dasar, pupuk tersebut ditebar dan diratakan pada masing-masing bedengan setelah selesai pengolahan lahan. Pupuk nitrogen dan pupuk fosfor diberikan pada saat tanam dan pada saat tanaman berumur 21 hari setelah tanam (hst), pupuk nitrogen yang digunakan yaitu pupuk urea sedangkan pupuk fosfor yang digunakan yaitu pupuk SP 36, cara pengaplikasinya pupuk SP 36 dihaluskan hingga menjadi serbuk, setelah itu digabungkan dengan pupuk urea dan dimasukan ke dalam lubang yang telah dibuat. Jarak antar lubang yang berisi benih dengan lubang yang berisi pupuk yaitu $5 \mathrm{~cm}$. Dengan dosis pupuk yang diberikan sesuai dengan taraf perlakuan yaitu untuk pupuk urea dibutuhkan 440 gram/petak dan 900 gram/petak urea dengan 2 kali pemberian jadi setiap 1 kali pemberian dosis yang digunakan yaitu 220 gram/petak dan 450 gram/petak urea. Sedangkan untuk pupuk SP 36 dibutuhkan 960 gram/petak dan 1940 gram/petak SP 36 dengan 2 kali pemberian jadi setiap 1 kali pemberian dosis yang digunakan yaitu 480 gram/petak dan 970 gram/petak SP 36. Pemupukan diberikan antar tanaman, sehingga setiap aplikasi pada tiap 26 lubang pemupukan diberikan untuk N1 (11 gram/lubang), N2 $\quad(22,5$ gram/lubang), P1 (24 gram/lubang) dan P2 (48,5 gram/lubang).

\section{Pemeliharaan Tanaman}

1. Pengairan

Tanah bedengan harus dipertahankan tetap lembap supaya biji kacang panjang segera berkecambah dan tumbuh dengan baik, karena apabila kekurangan air dapat menghambat perkecambahan biji kacang panjang. Penyiraman dilakukan dua kali sehari yakni pada pagi dan sore hari dengan menggunakan gembor.

2. Pemasangan Ajir

Tanaman kacang panjang berkecambah sekitar 1 minggu setelah tanam. Setelah dua minggu tanaman kacang panjang membentuk tunas baru, pada waktu itu tanaman sudah harus diberi ajir sebagai tempat merambat, turus ditancapkan di dekat lubang tanam sedalam 30 cm. Ajir dapat ditancapkan tegak lurus membentuk format baris, untuk memperkuat kedudukan ajir tersebut bagian atasnya dipasang kayu lalu diikat dengan tali plastik 
Murdaningsih: Pengaruh pemberian dosis pupuk $\mathrm{N}$ dan $\mathrm{P}$ Terhadap pertumbuhan dan hasil Kacang panjang (Vigna sinensis $\mathrm{L}$ )

(rafia) sehingga saling berhubungan.

3. Penyiangan

Penyiangan dilakukan pada waktu tanaman berumur 2-3 minggu setelah tanam. Gulma yang tumbuh di bedengan maupun di saluran drainase harus dibersihkan. Penyiangan dilakukan dengan menggunakan alat bantu berupa cangkul atau tofa, penyiangan harus dilakukan dengan hati-hati agar tidak merusak tanaman. Bersamaan dengan kegiatan penyiangan dilakukan pula pembenahan tanaman dan perbaikan bedengan.

\section{Panen}

Panen tanaman kacang panjang dilakukan pada umur 43 hst. Panen dilakukan sebanyak 2 kali dengan interval panen 4 hari. Waktu pelaksanaan panen pada pagi hari saat cuaca cerah.

\section{Variabel Pengamatan}

Pada penelitian ini pengamatan dilakukan terhadap: variabel pertumbuhan

1. Diameter Batang $(\mathrm{cm})$

Pengukuran diameter batang dilakukan dengan mengukur batang yang berada di atas tanah yang berdiameter paling besar. Jarak antara tanah dengan diameter batang yang diukur yaitu $5 \mathrm{~cm}$, pengukurannya dengan menggunakan jangka sorong. Pengamatan dimulai pada saat tanaman berumur 14 hst, 21 hst, 28 hst dengn interval waktu pengukuran seminggu sekali.

2. Jumlah Daun (helai)

Perhitungan jumlah daun pada tanaman dilakukan dengan menghitung semua daun yang telah terbuka sempurna, tetapi untuk tanaman kacang panjang karena daunnya disebut daun trifolia yang artinya dalam satu tangkai terdapat 3 helai daun maka setiap tangkai dihitungnya satu. Waktu pengamatan dimulai pada saat tanaman berumur 14 hst, 21 hst, 28 hst dengan interval waktu pengukuran seminggu sekali.

\section{Luas Daun}

Penghitungan luas daun dilakukan dengan menggunakan metode kertas milimeter dengan cara menggambar daun pada kertas milimeter. Setelah itu dihitung berapa jumlah kotak yang terdapat dalam gambar daun, kotak yang 
Murdaningsih: Pengaruh pemberian dosis pupuk $\mathrm{N}$ dan $\mathrm{P}$ Terhadap pertumbuhan dan hasil Kacang panjang (Vigna sinensis $\mathrm{L}$ )

setengah dan lebih dihitung 1

kotak. Waktu pengamatan dimulai

pada saat tanaman berumur 14

hst, 21 hst, 28 hst dengan interval

waktu pengukuran seminggu

sekali. Dengan menggunakan

rumus: $\mathrm{LD}=\mathrm{n} \times \mathrm{Lk}$

Keterangan $=$ LD: Luas

daun, n: jumlah kotak, Lk: luas setiap kotak.

\section{Variabel Produksi}

\section{Panjang Polong}

Pengukuran panjang polong dilakukan pada saat panen polong dan pengukuran dilakukan seminggu sekali. Pengukuran panjang polong dilakukan dengan menggunakan penggaris atau meteran.

2. Diameter Polong

Pengukuran diameter polong dilakukan pada saat dipanen dengan mengukur pada bagian tengah polong pada tiap tanaman sampel. Pengukuran diameter polong dengan menggunakan jangka sorong.

3. Jumlah Polong Pertanaman

$\begin{array}{rrr}\text { Dilakukan dengan cara } & \text { buah } \\ \text { menghitung } & \text { seluruh } \\ \text { pertanaman pada masing-masing }\end{array}$

tanaman sampel kemudian dirataratakan dan dilakukan pada saat panen.

4. Berat Segar Polong Pertanaman

Pengamatan berat segar polong pertanaman dilakukan dengan cara menimbang polong muda dari setiap tanaman sampel dengan menggunakan alat timbang elektrik.

5. Berat Segar Polong per hektar Pengamatan berat segar polong per hektar dilakukan dengan cara mengkalikan berat segar polong pertanaman dengan populasi dengan menggunakan rumus

Berat Segar Polong/hektar = BSP per tanaman X Populasi/ ha

Keterangan: $\mathrm{BSP}=$ Berat Segar Polong

6. Berat Segar Brangkasan per tanaman

Berat brangkasan segar per tanaman diperoleh dengan cara mengambil bagian tanaman yang ada diatas tanah dan akar kemudian ditimbang dalam keadaan basah ( segar).

7. Berat Segar Brangkasan per hektar Berat brangkasan segar per hektar diperoleh dengan menghitung 
Murdaningsih: Pengaruh pemberian dosis pupuk $\mathrm{N}$ dan $\mathrm{P}$ Terhadap pertumbuhan dan hasil Kacang panjang (Vigna sinensis $\mathrm{L}$ )

perbandingan berat segar

brangkasan per tanaman dengan

populasi per hektar dengan

menggunakan rumus

$\mathrm{BSB}$ per hektar $=\mathrm{BSB}$ per

tanaman x Populasi / ha

8. Indeks Panen

Indeks panen merupakan perbandingan antara hasil ekonomi (polong) dengan hasil biologis (polong + brangkasan) dalam keadaan segar dengan menggunakan rumus menurut (Martini, 1994)

$\mathrm{IP}=\underline{\text { Hasil polong segar ha }} \quad \mathrm{X} 100 \%$

Hasil biologi segar ha + Berat segar Brangkasan

Analisis Data

Data yang dikumpulkan dianalisis secara statistik dengan menggunakan analisis varian (sidik ragam) sesuai dengan rancangan yang digunakan. Bila pengaruh interaksi terhadap variabel yang diamati, maka dilanjutkan dengan uji DMRT. Apabila faktor tunggal yang berpengaruh nyata maka dilanjutkan dengan uji BNT taraf 5\% (Gomez dan Gomez 1995).

\section{HASIL DAN PEMBAHASAN}

Dari hasil analisis statistik pada tabel signifikasi menunjukan tidak terjadi interaksi antara pemberian pupuk nitrogen dan pupuk fosfor terhadap

variabel pertumbuhan dan hasil pada semua umur pengamatan. Hal ini disebabkan karena kandungan unsur hara dalam tanah tergolong rendah sehingga mengakibatkan perpaduan antara pupuk nitrogen dan pupuk fosfor tidak memberikan interaksi.

\section{Variabel Pertumbuhan}

\section{Diameter batang, Luas daun dan Jumlah daun}

Hasil penelitian menunjukan bahwa interaksi antara pupuk nitrogen (urea) dan pupuk fosfor (SP36) tidak memberikan pengaruh yang nyata terhadap diameter batang, luas daun dan jumlah daun, namun pengaruh yang nyata terjadi pada masing-masing perlakuan, pengaruh nyata terjadi pada masing-masing perlakuan disebabkan karena pupuk nitrogen sangat dibutuhkan tanaman kacang panjang untuk proses pertumbuhan vegetatifnya, selain itu tanaman kacang panjang adalah jenis tanaman yang mempunyai akar berbintil yang dapat mengikat nitrogen $(\mathrm{N})$ bebas dari udara ( Tuhana Taufiq dan Novo Indarto, 2004 ). Sedangkan pupuk fosfor berguna untuk pertumbuhan generative tanaman, selain pupuk fosfor juga dibutuhkan tanaman untuk menysusun $0,1-0,4$ bahan kering tanaman. Unsur ini sangat penting 
Murdaningsih: Pengaruh pemberian dosis pupuk $\mathrm{N}$ dan $\mathrm{P}$ Terhadap pertumbuhan dan hasil Kacang panjang (Vigna sinensis $\mathrm{L}$ )

didalam proses fotosintesis dan fisologis

kimiawi tanaman (Redaksi Agromedia, 2007).

Hasil penelitian menunjukan bahwa pengaruh pemberian pupuk nitrogen dan pupuk fosfor memberikan pengaruh nyata terhadap diameter batang, jumlah daun dan luas daun pada umur pengamatan 21 dan 28 hari setelah tanam, sedangkan pada umur pengamatan 14 hari setelah tanam belum memberikan pengaruh nyata. Hasil pengamatan diameter batang, jumlah daun dan luas daun yang berumur 21 dan 28 hari setelah tanam perlakuan pupuk nitrogen dengan dosis $60 \mathrm{~kg} / \mathrm{ha}$ dan perlakuan pupuk fosfor dengan dosis $100 \mathrm{~kg} / \mathrm{ha}$ memberikan hasil yang paling baik. Dari hasil penelitian pupuk nitrogen dengan dosis $60 \mathrm{~kg} / \mathrm{ha}$ memberikan hasil diameter batang tertinggi pada tiap hari pengamatan dengan rataan peningkatan 14 hst ke 21 hst sebesar 1,47\%, 21 hst ke 28 hst sebesar 1,29\%. Memberikan hasil jumlah daun yang paling banyak dengan presentase peningkatan sebesar $1,79 \%$ dan memberikan hasil luas daun yang paling baik pada tiap hari pengamatan dengan rataan peningkatan 14 hst ke 21 hst sebesar 2,39\%, 21 hst ke 28 hst $1,28 \%$. Peningkatan dosis pupuk nitrogen dapat meningkatkan pertumbuhan tanaman hal ini disebabkan karena fungsi nitrogen secara langsung berperan dalam pembentukan protein dan memperbaiki pertumbuhan vegetatif tanaman (Hardjowigeno, 1987; Tri Mulat, 2003). Ha ini disebabkan juga karena unsur $\mathrm{N}$ berperan dalam pertumbuhan tanaman, perihal ini sesuai dengan pendapat Nyakpa (1988) bahwa bilamana terjadi kekurangan unsur hara $\mathrm{N}$ maka pada tanaman akan terjadi penghentian proses pertumbuhan, sedangkan bila jumlahnya cukup tersedia akan membantu dalam proses pertumbuhan organ vegetative tanaman. Menurut Rinsema (1993) nitrogen ditinjau dari berbagai sudut dapat memberikan pengaruh positif yaitu berpengaruh besar dalam menaikkan potensi pembentukan daun-daunan. Dengan demikian hipotesis penggunaan pupuk nitrogen dengan dosis $60 \mathrm{~kg} / \mathrm{ha}$ terbukti.

Sedangkan dari hasil penelitian menunjukan bahwa pemberian dosis pupuk fosfor $100 \mathrm{~kg} / \mathrm{ha}$ memberikan hasil yang terbaik pada pengamatan diameter batang dengan memberikan hasil diameter batang tertinggi pada tiap hari pengamatan dengan rataan peningkatan 14 hst ke 21 hst sebesar 
Murdaningsih: Pengaruh pemberian dosis pupuk $\mathrm{N}$ dan $\mathrm{P}$ Terhadap pertumbuhan dan hasil Kacang panjang (Vigna sinensis L)

1,43\%, 21 hst ke 28 hst sebesar 1,30\%.

Memberikan hasil jumlah daun yang paling banyak dengan presentase peningkatan sebesar $1,81 \%$ dan memberikan hasil luas daun yang paling baik pada tiap hari pengamatan dengan rataan peningkatan 14 hst ke 21 hst sebesar 2,41\%, 21 hst ke 28 hst sebesar $1,27 \%$. Hal ini sesuai dengan pendapat Buckman dan Brady (1982) yang menyatakan didalam tanaman unsur fosfor merupakan unsur yang mobile (bergerak) dan bilamana terjadi kekurangan unsur ini pada suatu tanaman maka unsur fosfor pada jaringan-jaringan tua akan ditranslokasikan ke jaringan yang masih efektif. Sehingga hipotesis dari penggunaan dosis pupuk fosfor 100 $\mathrm{kg} / \mathrm{ha}$ terbukti, namun pada perlakuan dosis pupuk nitrogen $60 \mathrm{~kg} / \mathrm{ha}(\mathrm{N} 2)$ dan $30 \mathrm{~kg} / \mathrm{ha}$ (N1) serta perlakuan dosis pupuk fosfor $100 \mathrm{~kg} / \mathrm{ha}(\mathrm{P} 2)$ dan 50 $\mathrm{kg} / \mathrm{ha}$ (P1) tidak berbeda nyata hal ini disebabkan karena kondisi tanah yang dilihat dari hasil analisis menunjukan kandungan nitrogen dan fosfor dalam tanah rendah sehingga mengakibatkan perlakuan dosis pupuk $\mathrm{N} 2(60 \mathrm{~kg} / \mathrm{ha})$ dan N1 (30 kg/ha) serta P2 (100 kg/ha) dan P1 (50 kg/ha) tidak berbeda nyata.

\section{Variabel Hasil}

Tabel 4.3 Pengaruh dosis pupuk nitrogen dan pupuk fosfor terhadap Panjang Polong $(\mathrm{cm})$, Diameter Polong $(\mathrm{mm})$, Jumlah polong tan- ${ }^{1}$, Berat segar polong tan-1, dan Berat segar polong ton/ha.

\begin{tabular}{cccccc}
\hline & \multicolumn{5}{c}{ Variabel Pengamatan Hasil } \\
\cline { 2 - 6 } Perlakuan & $\begin{array}{l}\text { Panjang } \\
\text { Polong } \\
(\mathrm{cm})\end{array}$ & $\begin{array}{l}\text { Diameter } \\
\text { Polong } \\
(\mathrm{mm})\end{array}$ & $\begin{array}{l}\text { Jumlah } \\
\text { Polong } \\
\text { tan-1 }\end{array}$ & $\begin{array}{l}\text { Berat Segar } \\
\text { Polong tan-1 } \\
(\mathrm{gr})\end{array}$ & $\begin{array}{l}\text { Berat Segar } \\
\text { Polong } \\
\text { ton/ha }\end{array}$ \\
\hline N0 & $69.98 \mathrm{~b}$ & $5.78 \mathrm{~b}$ & $7.66 \mathrm{~b}$ & $58.89 \mathrm{~b}$ & $16.83 \mathrm{~b}$ \\
N1 & $70.78 \mathrm{a}$ & $6.13 \mathrm{a}$ & $7.98 \mathrm{a}$ & $61.09 \mathrm{a}$ & $17.46 \mathrm{a}$ \\
N2 & $71.47 \mathrm{a}$ & $6.26 \mathrm{a}$ & $8.22 \mathrm{a}$ & $62.68 \mathrm{a}$ & $17.91 \mathrm{a}$ \\
BNT 5 \% & 0.75 & 0.21 & 0.25 & 2.12 & 0.61 \\
P0 & $70.03 \mathrm{~b}$ & $5.81 \mathrm{~b}$ & $7.67 \mathrm{~b}$ & $58.21 \mathrm{~b}$ & $16.63 \mathrm{~b}$ \\
P1 & $70.90 \mathrm{a}$ & $6.16 \mathrm{a}$ & $8.00 \mathrm{a}$ & $61.84 \mathrm{a}$ & $17.67 \mathrm{a}$ \\
P2 & $71.30 \mathrm{a}$ & $6.20 \mathrm{a}$ & $8.19 \mathrm{a}$ & $62.62 \mathrm{a}$ & $17.89 \mathrm{a}$ \\
\hline BNT 5 \% & 0.75 & 0.21 & 0.25 & 2.12 & 0.61 \\
\hline
\end{tabular}

Keterangan : Angka-angka yang diikuti oleh huruf yang sama pada kolom yang sama berarti tidak berbeda nyata pada taraf uji BNT 5\%.

Hasil analisis sidik ragam menunjukan pemberian pupuk nitrogen dan pupuk fosfor memberikan pengaruh nyata terhadap Panjang Polong, Diameter Polong, Jumlah Polong per tanaman, Berat Segar Polong per tanaman dan Berat Segar Polong per hektar pada masing-masing perlakuan. Pemberian dosis pupuk nitrogen dan dosis pupuk fosfor pada setiap umur pengamatan dapat meningkatkan Panjang Polong, Diameter Polong, 
Murdaningsih: Pengaruh pemberian dosis pupuk $\mathrm{N}$ dan $\mathrm{P}$ Terhadap pertumbuhan dan hasil Kacang panjang (Vigna sinensis $\mathrm{L}$ )

Jumlah Polong per tanaman, Berat

Segar Polong per tanaman, Berat Segar

Polong per hektar. Tabel 4.3 menunjukan bahwa pemberian pupuk nitrogen pada setiap umur pengamatan memberikan peningkatan presentase pada perlakuan dosis $30 \mathrm{~kg} / \mathrm{ha}$ meningkatkan rataan total sebesar 4,64\%, dosis $60 \mathrm{~kg} / \mathrm{ha}$ sebesar 4,79\%.Pada tabel 4.3 menunjukan bahwa pemberian pupuk fosfor pada setiap umur pengamatan juga mengalami peningkatan presentase pada perlakuan dosis $50 \mathrm{~kg} / \mathrm{ha}$ meningkatkan rataan total sebesar $4,70 \%$, dosis 100 $\mathrm{kg} / \mathrm{ha}$ sebesar 4,77\%. Namun pada perlakuan $\mathrm{N} 2$ dan $\mathrm{N} 1$ tidak berbeda nyata hal ini disebabkan karena dosis pupuk pada perlakuan N2 dan N1 belum secara optimal menambah unsur hara nitrogen didalam tanah, dimana kandungan $\mathrm{N}$ didalam tanah hanya tersedia $0,18 \%$ (rendah) sehingga mengakibatkan hasil produksi pada perlakuan N2 dan N1 tidak berbeda nyata, begitu pun dengan perlakuan P2 dan $\mathrm{P} 1$ yang dimana kandungan $\mathrm{P}$ didalam tanah hanya tersedia 14,64 ppm (rendah), sehingga mengakibatkan hasil produksi pada perlakuan $\mathrm{P} 2$ dan $\mathrm{P} 1$ tidak berbeda nyata. Hasil analisis sidk ragam menunjukan bahwa tidak terjadi interaksi antara pemberian pupuk nitrogen dan pupuk fosfor terhadap Berat Brangkasan segar per tanaman, Berat Brangkasan segar per hektar dan Index Panen, namun pengaruh yang nyata terjadi pada masing-masing perlakuan yang diberikan. Pemberian dosis pupuk nitrogen dan dosis pupuk fosfor pada setiap umur pengamatan dapat meningkatkan Berat Brangkasan segar per tanaman, Berat Brangkasan Segar per hektar, dan Index Panen. Tabel 4.4 menunjukan bahwa pemberian dosis pupuk nitrogen pada setiap umur pengamatan memberikan peningkatan presentase pada perlakuan dosis $30 \mathrm{~kg} / \mathrm{ha}$ meningkatkan rataan total sebesar 5,58\%, dosis $60 \mathrm{~kg} / \mathrm{ha}$ sebesar $5,97 \%$. 
Murdaningsih: Pengaruh pemberian dosis pupuk $\mathrm{N}$ dan $\mathrm{P}$ Terhadap pertumbuhan dan hasil Kacang panjang (Vigna sinensis $\mathrm{L}$ )

Tabel 4.4 Pengaruh dosis pupuk nitrogen dan pupuk fosfor terhadap Berat Brangkasan segar tan-1, Berat brangkasan segar /ha, dan Index panen

\begin{tabular}{|c|c|c|c|}
\hline \multirow[b]{2}{*}{ Perlakuan } & \multicolumn{3}{|c|}{ Variabel Pengamatan Hasil } \\
\hline & $\begin{array}{l}\text { BBS } \\
\tan ^{-1} \\
\text { (gr) }\end{array}$ & $\begin{array}{l}\text { BBS } \\
\text { ha-1 } \\
\text { (ton) }\end{array}$ & $\begin{array}{c}\text { Index panen } \\
(\%)\end{array}$ \\
\hline N0 & $55.56 \mathrm{~b}$ & $15.86 \mathrm{~b}$ & $32.94 \mathrm{~b}$ \\
\hline N1 & $59.67 \mathrm{a}$ & $17.05 \mathrm{a}$ & $35.43 \mathrm{a}$ \\
\hline $\mathrm{N} 2$ & $62.56 \mathrm{a}$ & $17.87 \mathrm{a}$ & $36.00 \mathrm{a}$ \\
\hline BNT $5 \%$ & 3.99 & 1.14 & 1.95 \\
\hline P0 & $55.33 \mathrm{~b}$ & $15.81 \mathrm{~b}$ & $32.90 \mathrm{~b}$ \\
\hline P1 & $59.78 \mathrm{a}$ & $17.08 \mathrm{a}$ & $35.52 \mathrm{a}$ \\
\hline P2 & $62.67 \mathrm{a}$ & $17.89 \mathrm{a}$ & $35.94 \mathrm{a}$ \\
\hline BNT $5 \%$ & 3.99 & 1.14 & 1.95 \\
\hline
\end{tabular}

Keterangan : Angka-angka yang diikuti oleh huruf yang sama pada kolom yang sama berarti tidak berbeda nyata pada taraf uji BNT 5\%

Pada tabel 4.4 menunjukan bahwa sehingga unsur hara yang dibutuhkan pemberian dosis pupuk fosfor pada tanaman kacang panjang terpenuhi, setiap umur pengamatan juga dengan demikian hipotesis penggunaan mengalami peningkatan presentase pada pupuk nitrogen dengan dosis $60 \mathrm{~kg} / \mathrm{ha}$ perlakuan dosis $50 \mathrm{~kg} / \mathrm{ha}$ meningkatkan dan pupuk fosfor dengan dosis 100 rataan total sebesar 5,64\%, dosis 100 $\mathrm{kg} / \mathrm{ha}$ sebesar 5,95\%. Hal ini $\mathrm{kg} / \mathrm{ha}$ terbukti. Namun pada perlakuan menunjukan bahwa peningkatan pemberian dosis pupuk nitrogen dan pupuk fosfor dapat meningkatkan pertumbuhan dan hasil yang berbeda pada tiap dosis perlakuan, dari hasil penelitian diperoleh bahwa perlakuan dosis pupuk N2P2 $(60 \mathrm{~kg} / \mathrm{ha}$ urea dan $100 \mathrm{~kg} / \mathrm{ha} \mathrm{SP}$ 36) memberikan hasil yang paling baik. Hal ini disebabkan karena selama pertumbuhan tanaman terjadi perpindahan berbagai unsur hara ke dalam tubuh tanaman N2 dan N1 tidak berbeda nyata hal ini disebabkan karena dosis pupuk pada perlakuan N2 dan N1 belum secara optimal menambah unsur hara nitrogen didalam tanah sehingga mengakibatkan hasil produksi pada perlakuan N2 dan N1 tidak berbeda nyata, begitu pun pada perlakuan P2 dan P1. Karena dilihat dari kondisi tanah kandungan unsur hara $\mathrm{N}$ didalam tanah hanya $0,18 \%$ (rendah) dan kandungan unsur hara $\mathrm{P}$ didalam tanah hanya 14,64 ppm (rendah).

(Sosrosoedirdjo dkk, 1992), sehingga terjadi keseimbangan penyerapan hara 
Murdaningsih: Pengaruh pemberian dosis pupuk $\mathrm{N}$ dan $\mathrm{P}$ Terhadap pertumbuhan dan hasil Kacang panjang (Vigna sinensis $\mathrm{L}$ )

\section{KESIMPULAN}

1. Tidak terjadi interaksi antara pemberian pupuk nitrogen dan pupuk fosfor pada variabel pertumbuhan dan hasil.

2. Pemberian pupuk nitrogen dengan dosis $60 \mathrm{~kg} / \mathrm{ha}(\mathrm{N} 2)$ berpengaruh nyata terhadap diameter batang $(3,64 \%)$, jumlah daun $(5,64 \%)$, luas daun $(4.16 \%)$, panjang polong $(4.21 \%)$, diameter polong $(4,06 \%)$, jumlah polong $(2,54 \%)$, berat segar polong per tanaman $(5,47 \%)$, berat segar polong per hektar $(3,69 \%)$, berat brangkasan segar per tanaman $(5,32 \%)$, berat brangkasan segar per hektar $(3,60 \%)$ dan index panen $(3,18 \%)$ namun tidak berbeda nyata dengan dosis pupuk nitrogen 30 $\mathrm{kg} / \mathrm{ha}(\mathrm{N} 1)$.

3. Pemberian pupuk fosfor dengan dosis $100 \mathrm{~kg} / \mathrm{ha}(\mathrm{P} 2)$ berpengaruh nyata terhadap diameter batang $(4,73$ $\mathrm{mm})$, jumlah daun (9,37 helai), luas daun $(65,80 \mathrm{~cm})$, panjang polong $(47,73 \mathrm{~cm})$, diameter polong $(4,26$ $\mathrm{mm})$, jumlah polong (2,59 buah), berat segar polong per tanaman $(62,30 \mathrm{~g})$, berat segar polong per hektar (42,31 ton/ha), berat brangkasan segar per tanaman $(62,56$ g), berat brangkasan segar per hektar (43.00 ton/ha) dan index panen $(2,76)$ namun tidak berbeda nyata dengan dosis pupuk fosfor $50 \mathrm{~kg} / \mathrm{ha}$ (P1).

\section{DAFTAR PUSTAKA}

Anonim. 2012. Laporan Dinas Pertanian dan Tanaman Pangan Hortikultura, Kabupaten Ende

Anonim. 2012. Nasional dan NTT Dalam Angka, BPS Kabupaten Ende.

Cahyono. 2005. Kacang Panjang (Teknik budidaya dan analisis usaha tani). Aneka Ilmu, Jakarta.

Gomez, K.A. Gomez, A.A. 1995, Prosedur Statistik Untuk Penelitian Pertanian. Universitas Indonesia, Jakarta.

Hanafiah. 2005. Ilmu Kesuburan Tanah. Kanisius. Yogyakarta

I Putu Wisardja. 2010. Pengaruh Dosis dan Cara Pemberian Pupuk Phosfat Terhadap Pertumbuhan dan Hasil Kacang Panjang. Skripsi

Mapegau. 2007. Pengaruh Pupuk Nitrogen Terhadap Pertumbuhan dan Hasil Tanaman Kacang Panjang. Skripsi

Redaksi Agromedia. 2007. Petunjuk Pemupukan. Agromedia Pustaka. Jakarta Selatan

Setijo Pitojo. 2006, Penangkaran Benih Kacang Panjang. Kanisius. Yogyakarta.

Soetedjo, M. M. 2002. Pupuk dan Cara Pemupukan. Rhineka Cipta, Jakarta.

Sosrosoedirdjo R. S. Bachtiar, R, Iskandar. P. 1992. Ilmu Метирuk 2. CV. Yasaguna. Anggota IKAPI.

Suherni, N. 2007. Petunjuk Praktis Menanam Kacang Panjang dan Buncis. Nuasa. Bandung. 